\title{
Effect of whey fermented by Enterococcus faecium in consortium with Veilonella parvula on ruminal bacteria in vitro
}

\author{
Higor Fábio Carvalho Bezerra ${ }^{1}$, Juliana Silva de Oliveira², Edson Mauro Santos ${ }^{2}$, Augusto \\ César de Queiroz ${ }^{2}$, Hilário Cuquetto Mantovani ${ }^{2}$, Ricardo Martins Araujo Pinho ${ }^{1}$, Jurandir \\ Queiroz de Oliveira Junior ${ }^{1}$, Elizabete Cristina Batista da Costa ${ }^{1}$
}

\footnotetext{
${ }^{1}$ Departamento de Zootecnia, Universidade Federal da Paraíba, Areia, PB, Brasil.

${ }^{2}$ Departamento de Zootecnia, Universidade Federal de Viçosa, Viçosa, MG, Brasil.
}

\begin{abstract}
The objective of this research was to evaluate the effect of whey fermented by Enterococus faecium in consortium with Veilonella parvula in vitro on ruminal microorganisms in different substrates, with or without monensin. The first experiment was carried out in a completely randomized design, in a $6 \times 3$ factorial arrangement (six substrates $\times$ three whey levels) with two replicates. In experiment two, a $2 \times 3 \times 4$ factorial arrangement (with and without monensin, three foods and four levels of fermented whey) was used, in a randomized design with four replicates, totaling 24 treatments. There was no interaction among the wheys and the substrates in the variable for pectin, starch, and carboxymethyl cellulose. There was a greater growth of amylolytic and pectinolytic microorganisms and a lower growth of proteolytic and cellulolytic microorganisms. A significant effect of optical density was found in the media without substrate and that containing trypticase and glucose due to the addition of fermented whey. There was interaction for the $\mathrm{pH}$ at 24 hours among whey, food and monensin. For ammonia at 24 hours there was effect for food, whey and monensin, and interaction among factors. For microbial protein at 24 hours, there was effect for food, whey, monensin and no interaction among sources of variation. The use of whey fermented by bacteria Enterococcus faecium and Veilonella parvula improves microbial protein synthesis by ruminal bacteria in media containing different energy sources. The combination of fermented whey and monensin shows variable results in relation to microbial growth.
\end{abstract}

Key Words: ammonia, fermentation, microbial protein, monensin, rumen, ruminal $\mathrm{pH}$

\section{Introduction}

Ruminants have the ability to use a large variety of foods as nutrient source due to the mutualistic relationship between the host (animal) and rumen microorganisms, which enables the use of complex compounds unusable for most other animals. Modifications in the rumen microbial ecosystem provide changes in nutrient availability for the ruminant.

Thus, there is much interest in alternatives to manipulate the ruminal microbiota. The rumen can be manipulated to improve the use of substrate and the efficiency of fermentation and use of food nutrients. Among the studied ruminal additives for ruminants, the organic acids and direct-fed microbials have stood out. These food additives act in different ways on ruminal fermentation, improving animal performance, without leaving residues in products of animal origin.

Received August 20, 2013 and accepted January 30, 2014

Corresponding author: higorfabiozoo@hotmail.com

http://dx.doi.org/10.1590/S1516-35982014000500006

Copyright (@) 2014 Sociedade Brasileira de Zootecnia. This is an Open Access article distributed under the terms of the Creative Commons Attribution Non-Commercial License, which permits unrestricted non-commercial use, distribution, and reproduction in any medium, provided the original work is properly cited.
Organic acids in the rumen may stimulate consumption of lactate by Selenomonas ruminantium by preventing or correcting the drop of ruminal $\mathrm{pH}$ associated with ruminal acidosis; reduce methanogenesis by reducing energy loss associated with methane production in the rumen; and present a complementary effect like buffer on ruminal $\mathrm{pH}$ (Castillo et al., 2004).

Themechanismofaction of direct-fedmicrobials (DFM) is not well understood yet, but it is believed that these microorganisms have attributes that enhance the rumen functionality (Weinberg et al., 2003). Research has shown beneficial effects of DFM in preventing ruminal acidosis (Krehbiel et al., 2003), improving dry matter digestibility and animal performance (Weinberg et al., 2003). However, some research studies did not show improvement of digestibility (Raeth-Knight et al., 2007).

A source of propionic acid and DFM can be produced from the fermentation of whey by two ruminal microorganisms: Enterococus faecium and Veilonella parvula. Lactose is a substrate from the genus Enterococcus $s p$ that produces lactate. This is used as an energy source by bacteria of the genus Veilonella sp, which has propionic acid among its end products of the fermentation (Ribeiro et al., 2009). 
In this context, the objective of this study was to evaluate the effect of whey fermented by Enterococus faecium in consortium with Veilonella parvula on ruminal microorganisms in vitro in different substrates, with or without the presence of monensin.

\section{Material and Methods}

The research was divided into two experiments. Both in vitro experiments were performed in the Laboratory of Anaerobic Microbiology, Department of Microbiology, Universidade Federal de Viçosa, Viçosa, Minas Gerais State, Brazil.

In the two assays the same fermented whey was used. It was initially dehydrated and resuspended in water so that it contained $40 \mathrm{~g} / \mathrm{L}$ lactose. Subsequently, the $\mathrm{pH}$ was adjusted to 7.0 with $\mathrm{NaOH}$ at $1.0 \mathrm{M}$. The whey was then autoclaved, saturated with carbon dioxide, and inoculated with Enterococcus faecium and Veilonella parvula (3\% of the medium). The whey was kept for 48 hours at $39^{\circ} \mathrm{C}$ with continuous $\mathrm{CO}_{2}$ bubbling, and $\mathrm{pH}$ constantly corrected to 7.0 by adding $\mathrm{NaOH}$; then, it was frozen for later use in incubations.

One liter of rumen fluid was collected from cattle fistulated in the rumen, and immediately transported to the laboratory in a thermos. It was then placed at rest for 30 minutes at $39{ }^{\circ} \mathrm{C}$, and, after the formation of the liquid interfaces, the intermediary fluid was removed and centrifuged at $5000 \mathrm{xg}$ for 10 minutes, discarding the supernatant to obtain the inoculum containing the active microbial population (pellet). The pellet formed, which contained the predominant microorganisms in the rumen fluid, was re-suspended in synthetic medium $(40 \mathrm{~mL}$ of saline solution A - which contains, per liter: $7.3 \mathrm{~g} \mathrm{~K}_{2} \mathrm{HPO}_{4} * 3 \mathrm{H}_{2} \mathrm{O}$; $40 \mathrm{~mL}$ of saline solution B - which contains, per liter: $6.0 \mathrm{~g}$ of $\mathrm{K}_{2} \mathrm{HPO}_{4}, 12.0 \mathrm{~g}$ of $\left(\mathrm{NH}_{4}\right) 2 \mathrm{SO}_{4}, 12.0 \mathrm{~g}$ of NaCl, $2.5 \mathrm{~g}$ of $\mathrm{MgSO}_{4} * 7 \mathrm{H} 2 \mathrm{O}$ and $1.6 \mathrm{~g}$ of $\mathrm{CaCl}^{*} 2 \mathrm{H}_{2} \mathrm{O} ; 0.50 \mathrm{~g}$ of yeast extract; $1.0 \mathrm{~g}$ of trypticase - Trypticase, BBL Microbiology Systems, Cockesyille, MD; $0.60 \mathrm{~g}$ of cysteine hydrochloride; $1.0 \mathrm{~mL}$ of resazurin; $4.0 \mathrm{~g}$ of sodium carbonate; and $870 \mathrm{~mL}$ of water) autoclaved and saturated with carbon dioxide. Another centrifugation was performed at $5000 \mathrm{xg}$ for 10 minutes, with the supernatant discarded again. The pellet formed in the last centrifugation was, then, re-suspended in synthetic medium autoclaved and saturated with carbon dioxide (Rumen Bacteria).

The fermented whey was centrifuged at 5,000 $\mathrm{x} g$ for 15 minutes and the supernatant from the centrifugation was usedinthedifferent combinations(whey). Thecentrifugation procedure was used so that the microorganisms inoculated in the whey did not constitute the fermented whey of the experiment, and thus, counted as ruminal microorganisms in the experimental units containing fermented whey, or were used as protein source.

The experimental design was completely randomized, in a $6 \times 3$ factorial arrangement (six substrates and three whey levels) with two replicates. The combinations were: no substrate (control), no substrate $+100 \mathrm{~mL} / \mathrm{L}$ and $200 \mathrm{~mL} / \mathrm{L}$, respectively, of whey in the medium; trypticase, trypticase $+100 \mathrm{~mL} / \mathrm{L}$ and $200 \mathrm{~mL} / \mathrm{L}$, respectively, of whey in the medium; starch, starch $+100 \mathrm{~mL} / \mathrm{L}$ and $200 \mathrm{~mL} / \mathrm{L}$, respectively, of whey in the medium; carboxymethyl cellulose, carboxymethyl cellulose $+100 \mathrm{~mL} / \mathrm{L}$ and $200 \mathrm{~mL} / \mathrm{L}$, respectively, of whey in the medium; pectin, pectin + $100 \mathrm{~mL} / \mathrm{L}$ and $200 \mathrm{~mL} / \mathrm{L}$, respectively, of whey in the medium; and glucose, glucose $+100 \mathrm{~mL} / \mathrm{L}$ and $200 \mathrm{~mL} / \mathrm{L}$, respectively, of whey in the medium.

All incubation tubes contained $0.2 \mathrm{~mL}$ of rumen bacteria, $40 \mathrm{mg}$ of the substrate of each combination and synthetic medium autoclaved and saturated with carbon dioxide in quantities required to reach $10 \mathrm{~mL}$ of medium in total in all the combinations. The incubations were performed in anaerobic tubes, in which the medium was saturated with carbon dioxide. The tubes were sealed and kept at $39^{\circ} \mathrm{C}$.

After 24 hours of incubation, the optical density of each experimental unit was determined in the spectrophotometer Spectronic 20D + (Thermo Electron, Waltham, MA, USA) with wavelength of $600 \mathrm{~nm}\left(\mathrm{OD}_{600 \mathrm{~nm}}\right)$

An interaction effect was found between the substrate and the whey level $(\mathrm{P}<0.05)$. Therefore, the data were evaluated by regression analysis according to the concentration of fermented whey in the culture medium in each substrate. The significance of the quantitative effects $(\alpha=0.05)$ was taken as criterion for the choice of models.

In the second assay, the rumen fluid from a fistulated bovine was also collected and the same procedures were carried out as in the first assay to obtain the inoculum with active microorganisms. However, rather than re-suspending the pellet in saline solution, it was re-suspended in a synthetic medium.

The experimental design was completely randomized, in a $3 \times 2 \times 4$ factorial arrangement (three substrates, two levels of monensin and four levels of whey) with four replicates. The combinations were: starch with and without monensin plus $0,100,250$ and $500 \mathrm{~mL} / \mathrm{L}$, respectively, of whey in the medium; trypticase with and without monensin plus $0,100,250$ and $500 \mathrm{~mL} / \mathrm{L}$, respectively, of whey in the medium; cellulose with and without monensin plus 0,100 , 250 and $500 \mathrm{~mL} / \mathrm{L}$, respectively, of whey in the medium. 
All incubation tubes contained $4.5 \mathrm{~mL}$ of rumen bacteria, $150 \mathrm{mg}$ substrate of each compound, $0.1 \mathrm{~mL}$ ethanol (pure or with monensin), 0 or 1.0 or 2.5 or $5.0 \mathrm{~mL}$ autoclaved whey and synthetic medium autoclaved and saturated with carbon dioxide in sufficient quantities to reach $10 \mathrm{~mL}$ medium in total in all the compounds. The substrates used were trypticase as a source of protein, starch as a source nonfibrous carbohydrate and ground Whatman paper number 1 as a source of cellulose. An amount of monensin was added to the ethanol solution so that the final concentration was $15 \mu \mathrm{M}$ monensin in the culture medium.

The optical density of the medium at $600 \mathrm{~nm}$ was read by diluting $1.0 \mathrm{~mL}$ of the medium in approximately $10 \mathrm{~mL}$ of distilled water, to know the contents of cells in the treatments at 0 hour.

All incubation tubes were saturated with $\mathrm{CO}_{2}$, sealed, and kept (lying) at $39{ }^{\circ} \mathrm{C}$ under stirring (80 rpm) for 24 hours.

At 0 and 24 hours, $2.0 \mathrm{~mL}$ samples from each experimental unit were collected, placed in Eppendorf tubes for $\mathrm{pH}$ reading and subsequently centrifuged at 5,200 $\mathrm{xg}$ for 10 minutes, and the supernatant was frozen for later analysis of ammonia concentration by the method of Chaney and Marbach (1962). The pellet was re-suspended in saline solution $(0.9 \% \mathrm{NaCl})$, centrifuged again and separated from the supernatant, then re-suspended in saline solution $(0.9 \% \mathrm{NaCl})$ and frozen for subsequent quantification of microbial protein by the method of Bradford (1976).

The results were submitted to analysis of variance and regression. The effect of whey levels was verified by the analysis of linear regression, adopting the significance of the regression parameters and the determination coefficient values as criteria for the choice of models. The different substrates were compared by Tukey's test at $5 \%$ significance in the first assay and by the average test at $5 \%$ probability in the second assay, using a statistical analysis program (SAEG, version 9.1).

\section{Results}

No interaction $(\mathrm{P}>0.05)$ was found among wheys and the substrates in the variable for pectin, starch and carboxymethyl cellulose. There was a higher growth of pectinolytic and amylolytic microorganisms and a lower growth of proteolytic and cellulolytic microorganisms (Table 1).

There was effect $(\mathrm{P}<0.05)$ of the optical density in the media without substrate, which contained trypticase and glucose due to the addition of fermented whey in the medium.
For the $\mathrm{pH}$ at 0 hour, there was no effect $(\mathrm{P}>0.05)$ when adding monensin (Table 2); this was expected, since monensin does not have a rapid action.

There was an interaction $(\mathrm{P}<0.05)$ between the foods and whey levels (Table 2), in which the fermented whey provided a linear increase in $\mathrm{pH}$ when the starch and trypticase were used as substrates, without adjusting the pattern for the increase in $\mathrm{pH}$ when using carboxymethyl cellulose as the substrate.

For $\mathrm{pH}$ at 24 hours, there was interaction $(\mathrm{P}<0.05)$ among whey, food and monensin (Table 3).

For ammonia at 0 hour of incubation (Table 4), there was no effect $(\mathrm{P}>0.05)$ for monensin, with the mean values of 10.30 and $10.22 \mathrm{mg} / \mathrm{dL}$ without addition and with addition of monensin, respectively, because this ionophore does not have a rapid action. An effect $(\mathrm{P}<0.05)$ was observed for food and whey, with no interaction between the sources of variation. The trypticase demonstrated greater effect among the other food used, with mean values

Table 1 - Mean values of microbial growth in different substrates and in different concentrations of whey fermented by Enterococcus faecium and Veilonella parvula, expressed as optical density $\left(\mathrm{OD}_{600 \mathrm{~nm}}\right)$ after 24 hours of incubation

\begin{tabular}{lccc}
\hline \multirow{2}{*}{ Substrate } & \multicolumn{3}{c}{ Whey levels $(\mathrm{mL} / \mathrm{L}), \%$} \\
\cline { 2 - 4 } & 0 & 100 & 200 \\
\hline No substrate & $0.110 \mathrm{bC}$ & $0.175 \mathrm{abC}$ & $0.211 \mathrm{aB}$ \\
Trypticase & $0.105 \mathrm{bC}$ & $0.231 \mathrm{aC}$ & $0.288 \mathrm{aB}$ \\
Starch & $0.510 \mathrm{aA}$ & $0.560 \mathrm{aA}$ & $0.488 \mathrm{aA}$ \\
Carboxymethyl cellulose & $0.163 \mathrm{aC}$ & $0.175 \mathrm{aC}$ & $0.190 \mathrm{aB}$ \\
Pectin & $0.489 \mathrm{aA}$ & $0.572 \mathrm{aA}$ & $0.489 \mathrm{aA}$ \\
Glucose & $0.283 \mathrm{bB}$ & $0.429 \mathrm{aB}$ & $0.502 \mathrm{aA}$ \\
Coefficient of variation, $\%$ & & 10.20 & \\
\hline
\end{tabular}

Means followed by the same lowercase letter in the row and uppercase letter in the column do not differ by Tukey's test at 0.05 probability.

Table 2 - Mean $\mathrm{pH}$ values in the rumen in different substrates, with and without monensin and in different concentrations of whey fermented with Enterococcus faecium and Veilonella parvula after 0 hour of incubation

\begin{tabular}{|c|c|c|c|c|}
\hline & \multicolumn{4}{|c|}{ Monensin } \\
\hline & \multicolumn{2}{|c|}{ Without } & \multicolumn{2}{|c|}{ With } \\
\hline & \multicolumn{2}{|c|}{$6.87 \mathrm{a}$} & \multicolumn{2}{|c|}{$6.89 \mathrm{a}$} \\
\hline \multirow{2}{*}{ Food } & \multicolumn{4}{|c|}{ Whey levels (mL/L) } \\
\hline & 0 & 100 & 250 & 500 \\
\hline Trypticase $^{1}$ & $6.73 \mathrm{~B}$ & $6.80 \mathrm{AB}$ & $6.97 \mathrm{~A}$ & $7.15 \mathrm{~A}$ \\
\hline $\operatorname{Starch}^{2}$ & $6.87 \mathrm{~A}$ & $6.92 \mathrm{~A}$ & $7.03 \mathrm{~A}$ & $7.22 \mathrm{~A}$ \\
\hline Carboxymethyl cellulose ${ }^{3}$ & $6.75 \mathrm{AB}$ & $6.71 \mathrm{~B}$ & $6.90 \mathrm{~B}$ & $6.83 \mathrm{~B}$ \\
\hline \multicolumn{5}{|c|}{$\begin{array}{l}{ }^{1} \hat{Y}=6.7351+0.0084 X ; r^{2}=0.98 \\
{ }^{2} \hat{Y}=6.8642+0.0071 X ; r^{2}=0.99 \\
{ }^{3} \hat{Y}=6.7975 \\
\text { Coefficient of variation }=1.63 \% \\
\text { Means followed by the same uppercase letter do not differ by Tukey's test at } 0.05 \\
\text { probability. }\end{array}$} \\
\hline
\end{tabular}


of $13.07 \mathrm{mg} / \mathrm{dL}$, while the starch showed $10.05 \mathrm{mg} / \mathrm{dL}$ and the carboxymethyl cellulose showed $7.64 \mathrm{mg} / \mathrm{dL}$.

The mean values of ammonia in the rumen increased linearly $(\mathrm{P}<0.05)$ with the inclusion of whey levels. The results adjusted to the linear model: $\hat{\mathrm{Y}}=9.4363+0.0388 * \mathrm{X}$ $\left(\mathrm{r}^{2}=0.80\right)$.

For ammonia at 24 hours, there was effect $(\mathrm{P}<0.05)$ for food, whey and monensin, and interaction among food, whey and monensin (Table 5).

For microbial protein at 0 hour, there was no effect $(\mathrm{P}>0.05)$ for monensin (Table 6), showing that monensin does not have a quick action. An interaction effect was observed between food and whey.

For microbial protein at 24 hours, there was effect $(\mathrm{P}<0.05)$ for food, whey and monensin, with no interaction among sources of variation (Table 7).

Table 3 - Mean $\mathrm{pH}$ values in the rumen in different substrates, with and without monensin, and in different concentrations of whey fermented by Enterococcus faecium and Veilonella parvula after 24 hours of incubation

\begin{tabular}{lcccc}
\hline \multicolumn{5}{c}{ Without monensin } \\
\hline \multirow{5}{*}{ Food } & \multicolumn{5}{c}{ Whey levels (mL/L) } \\
\cline { 2 - 5 } & 0 & 100 & 250 & 500 \\
\hline Trypticase $^{1}$ & $6.97 \mathrm{aA}$ & $7.02 \mathrm{aA}$ & $7.12 \mathrm{aA}$ & $7.17 \mathrm{aA}$ \\
Starch $^{2}$ & $5.50 \mathrm{bC}$ & $5.60 \mathrm{bC}$ & $5.87 \mathrm{bC}$ & $6.40 \mathrm{aC}$ \\
Carboxymethyl cellulose $^{3}$ & $5.80 \mathrm{bB}$ & $6.02 \mathrm{bB}$ & $6.50 \mathrm{bB}$ & $6.82 \mathrm{aB}$ \\
\hline & With monensin & \\
\hline & \multicolumn{5}{c}{ Whey levels $(\mathrm{mL} / \mathrm{L})$} \\
Food & 0 & 100 & 250 \\
\hline Trypticase $^{4}$ & $6.95 \mathrm{aA}$ & $7.00 \mathrm{aA}$ & $7.07 \mathrm{aA}$ & $7.12 \mathrm{aA}$ \\
Starch $^{5}$ & $5.80 \mathrm{aC}$ & $5.87 \mathrm{aC}$ & $6.15 \mathrm{aC}$ & $6.35 \mathrm{aC}$ \\
Carboxymethyl cellulose $^{6}$ & $6.42 \mathrm{aB}$ & $6.62 \mathrm{aB}$ & $6.72 \mathrm{aB}$ & $6.82 \mathrm{aB}$ \\
\hline
\end{tabular}

${ }^{1} \hat{Y}=6.9888+0.0040 X ; r^{2}=0.93$

${ }^{2} \hat{\mathrm{Y}}=5.4519+0.0184 \mathrm{X} ; \mathrm{r}^{2}=0.98$

${ }^{3} \hat{Y}=5.8447+0.0208 X ; r^{2}=0.96$

${ }^{4} \hat{Y}=6.9635+0.0034 X ; r^{2}=0.94$

$\hat{Y}=5.7998+0.0114 X ; r^{2}=0.96$

${ }^{6} \hat{\mathrm{Y}}=6.4964+0.0073 \mathrm{X} ; \mathrm{r}^{2}=0.86$

Coefficient of variation $=2.05 \%$

Means followed by the same lowercase letter in the same whey level and in the same food do not differ in relation to the addition of monensin by Tukey's test at 0.05 probability.

Means followed by the same uppercase letter in the same column do not differ by Tukey's test at 0.05 probability.

Table 4 - Mean values of ammonia in the rumen in different concentrations of whey fermented by Enterococcus faecium and Veilonella parvula, expressed in $\mathrm{mg} / \mathrm{dL}$ after 0 hour of incubation

\begin{tabular}{cccc}
\hline \multicolumn{4}{c}{ Whey levels $(\mathrm{mL} / \mathrm{L})^{1}$} \\
\hline 0 & 100 & 250 & 500 \\
\hline 9.24 & 9.67 & 11.02 & 11.09 \\
\hline
\end{tabular}

${ }^{1} \hat{\mathrm{Y}}=9.4363+0.0388 \mathrm{X} ; \mathrm{r}^{2}=0.80$

Coefficient of variation $=14.03 \%$
Table 5 - Mean values of ammonia in the rumen in different substrates, with and without monensin, and in different concentrations of whey fermented by Enterococcus faecium and Veilonella parvula, expressed in $\mathrm{mg} / \mathrm{dL}$ after 24 hours of incubation

\begin{tabular}{lcccc}
\hline \multicolumn{5}{c}{ Without monensin } \\
\hline \multirow{5}{*}{ Food } & 0 & 100 & 250 & 500 \\
\cline { 2 - 5 } & $90.89 \mathrm{aA}$ & $102.07 \mathrm{aA}$ & $103.82 \mathrm{aA}$ & $87.34 \mathrm{aA}$ \\
Trypticase $^{1}$ & $5.86 \mathrm{aB}$ & $7.59 \mathrm{aB}$ & $8.56 \mathrm{aC}$ & $13.90 \mathrm{aB}$ \\
Starch $^{2}$ & $7.00 \mathrm{bB}$ & $12.49 \mathrm{aB}$ & $18.14 \mathrm{aB}$ & $20.40 \mathrm{aB}$ \\
Carboxymethyl cellulose $^{3}$ & With monensin \\
\hline \multirow{5}{c}{ Whey levels $(\mathrm{mL} / \mathrm{L})$} \\
Food $^{5}$ & 0 & 100 & 250 \\
\hline Trypticase $^{4}$ & $54.92 \mathrm{bA}$ & $58.53 \mathrm{bA}$ & $55.69 \mathrm{bA}$ & $52.58 \mathrm{bA}$ \\
Starch $^{5}$ & $6.55 \mathrm{aC}$ & $7.62 \mathrm{aC}$ & $9.67 \mathrm{aC}$ & $11.89 \mathrm{aB}$ \\
Carboxymethyl cellulose $^{6}$ & $14.78 \mathrm{aB}$ & $17.24 \mathrm{aB}$ & $17.62 \mathrm{aB}$ & $16.29 \mathrm{aB}$ \\
\hline
\end{tabular}

${ }^{1} \hat{\mathrm{Y}}=91.6123+1.1426 \mathrm{X}-0.0246 \mathrm{X}^{2} ; \mathrm{r}^{2}=0.98$

${ }^{2} \hat{Y}=5.6572+0.1563 X ; r^{2}=0.96$.

${ }^{3} \hat{Y}=9.0412+0.2574 X ; r^{2}=0.86$.

${ }^{4} \hat{Y}=55.7509+0.1507 X-0.0043 X^{2} ; r^{2}=0.73$

${ }^{5} \hat{Y}=6.6426+0.1079 X ; r^{2}=0.99$

${ }^{6} \hat{\mathrm{Y}}=15.0188+0.2096 \mathrm{X}-0.0037 \mathrm{X}^{2} ; \mathrm{r}^{2}=0.91$

Coefficient of variation $=13.48 \%$

Means followed by the same lowercase letter in the same whey level and in the same food do not differ in relation to monensin by Tukey's test at 0.05 probability.

Means followed by the same uppercase letter in the same column do not differ by

Tukey's test at 0.05 probability.

Table 6 - Mean values of microbial growth in different substrates, with and without monensin, and in different concentrations of whey fermented by Enterococcus faecium and Veilonella parvula, expressed as microbial protein concentration $(\mathrm{mg} / \mathrm{L})$ after 0 hour of incubation

\begin{tabular}{|c|c|c|c|c|}
\hline & \multicolumn{4}{|c|}{ Monensin } \\
\hline & \multicolumn{2}{|c|}{ Without } & \multicolumn{2}{|c|}{ With } \\
\hline & \multicolumn{2}{|c|}{$1,028.31 \mathrm{a}$} & \multicolumn{2}{|c|}{$980.98 \mathrm{a}$} \\
\hline \multirow{2}{*}{ Food } & \multicolumn{4}{|c|}{ Whey levels $(\mathrm{mL} / \mathrm{L})$} \\
\hline & 0 & 100 & 250 & 500 \\
\hline Trypticase $^{1}$ & $728.64 \mathrm{~A}$ & $904.74 \mathrm{~A}$ & $1,139.24 \mathrm{AB}$ & $1,073.02 \mathrm{~B}$ \\
\hline $\operatorname{Starch}^{2}$ & $838.37 \mathrm{~A}$ & $872.70 \mathrm{~A}$ & $1,046.34 \mathrm{~B}$ & $1,589.91 \mathrm{~A}$ \\
\hline Carboxymethyl cellulose ${ }^{3}$ & $369.50 \mathrm{~B}$ & $700.84 \mathrm{~A}$ & $1,349.75 \mathrm{~A}$ & $1,442.96 \mathrm{~A}$ \\
\hline
\end{tabular}

${ }^{1} \hat{Y}=25.2765+715.4057 X-0.3611 X^{2} ; r^{2}=0.98$

${ }^{2} \hat{Y}=757.3141+15.5068 X ; r^{2}=0.94$

${ }^{3} \hat{Y}=504.2903+21.7164 X ; r^{2}=0.83$

Coefficient of variation $=20.70 \%$

\section{Discussion}

The concentrations of ruminal microorganisms increased in the medium as fermented whey was added, which can be explained by the presence of organic acids in the whey that provided conditions for a more appropriate fermentation to proteolytic microorganisms and fermenters of nonstructural carbohydrates (Table 1). 
Table 7 - Mean values of microbial growth in different substrates, with and without monensin, and in different concentrations of whey fermented by Enterococcus faecium and Veilonella parvula, expressed as microbial protein concentration $(\mathrm{mg} / \mathrm{L})$ after 24 hours of incubation

\begin{tabular}{cccc}
\hline \multicolumn{3}{c}{ Monensin } \\
\hline \multicolumn{3}{c}{ Without } \\
$1,133.90 \mathrm{a}$ & \multicolumn{2}{c}{ With } \\
\multicolumn{4}{c}{ Food } \\
\hline Trypticase & Starch & Carboxymethyl cellulose \\
$950.37 \mathrm{~b}$ & $1,238.81 \mathrm{a}$ & \multicolumn{2}{c}{$882.84 \mathrm{~b}$} \\
\hline \multicolumn{5}{c}{ Whey levels $(\mathrm{mL} / \mathrm{L})^{1}$} \\
\hline 0 & 100 & 250 & 500 \\
742.85 & 952.01 & $1,092.86$ & $1,308.31$ \\
\hline
\end{tabular}

${ }^{1} \hat{\mathrm{Y}}=10.7253+796.0982 \mathrm{X} ; \mathrm{r}^{2}=0.96$.

Coefficient of variation $=23.13 \%$

Means followed by the same lowercase letter in the row do not differ by Tukey's test at 0.05 probability.

The fermented whey stimulated the growth of bacteria in medium containing glucose or trypticase, due, perhaps, to the fact that part of the population of proteolytic microorganisms and fermenters of nonstructural carbohydrates are more resistant to higher levels of organic acids (propionic acid and lactate) in the medium, decreasing the substrate competition between these microorganisms and others sensitive to organic acid. In addition, the whey may have provided additional substrate (lactate) to be fermented by certain groups of bacteria, favoring microbial growth.

Several ruminal bacteria are able to grow in low $\mathrm{pH}$ media and use both glucose and lactate as energy source, such as Selenomonas ruminantium, which is present in large amounts in the rumen of animals, and Megasphaera elsdenii. Selenomonas ruminantium strains, which use lactate, grow in media rich in glucose, accumulating lactate that can be used to form acetate and propionate. Megasphaera elsdenii is another bacterium that ferments a variety of simple sugars, but has high affinity for lactic acid (Russell, 2002) and is also resistant to $\mathrm{pH}$ decrease.

Bacteria with high specific activity of fermenting amino acids use amino acids as the main energy substrate, degrading proteins more strongly than others (Russell, 2002). However, excessive deamination of amino acids resulting from the fermentation of these bacteria causes loss of nitrogen in ammonia form, decreasing the nitrogen utilization efficiency and microbial growth. According to Leopoldino et al. (2005), acidity reduces ammonia production by inhibiting the growth of proteolytic bacteria population.
There was no effect $(\mathrm{P}>0.05)$ when the substrate in the medium was starch or pectin, having no microbial growth with the inclusion of the fermented whey. There was a small increase in microbial growth with the substrate starch or pectin when there was $100 \mathrm{~mL} / \mathrm{L}$ whey in the medium, and a decrease when $200 \mathrm{~mL} / \mathrm{L}$ were added. The initial increase in microbial growth may also be due to the presence of organic acids of the whey that improved microbial fermentation. However, adding larger amounts of fermented whey in the medium may result in toxic levels of lactate and propionic acid to the amylolytic and pectinolytic microorganisms, inhibiting their growth, which explains the decrease with the addition of $20 \mathrm{~mL} / \mathrm{L}$ whey. Amylolytic and pectinolytic microorganisms may be more sensitive to propionic acid and lactate than proteolytic microorganisms and other fermenters of nonstructural carbohydrate.

In the medium containing carboxymethyl cellulose as substrate, there was no effect $(\mathrm{P}>0.05)$ of fermented whey on microbial growth. This may be because cellulolytic microorganisms are not affected by constituents of fermented whey, more precisely by organic acids. Nevertheless, studies show that cellulolytic bacteria are one of the groups most susceptible to drop in $\mathrm{pH}$ (Russell and Strobel, 2005). As one of the main effects of propionic acid and lactate is decrease of $\mathrm{pH}$, the results of this assay contradict the results obtained by Russell and Strobel (2005).

These increases with the addition of fermented whey occurred exactly because the whey already had a higher $\mathrm{pH}$ (Table 2).

The effect of monensin $(\mathrm{P}<0.05)$ was observed for starch and carboxymethyl cellulose, in which the media without monensin had their $\mathrm{pH}$ decreased. Oliveira et al. (2005) reported that animals fed diets with high percentages of grains have an increase in the growth of Streptococcus bovis, resulting in a higher lactate production, leading to a marked drop in $\mathrm{pH}$ and symptoms of acidosis. This shows that monensin is highly beneficial for inhibiting the development of these bacteria and increasing the ruminal pH (Krehbiel et al., 2003).

Concerning the foods, trypticase showed higher $\mathrm{pH}$ values both with and without monensin. In the same way, Lana et al. (2007), evaluating the in vitro degradability of some foods, found lower $\mathrm{pH}$ reduction for the foods with high protein content. Starch had the lowest values both with and without monensin (Table 3 ). The addition of fermented whey caused a linear increase $(\mathrm{P}<0.05)$ in $\mathrm{pH}$ values for all foods in both the presence and absence of monensin, which can be explained by the higher of $\mathrm{pH}$ the whey, since its effect was observed when it was added at 0 hour. Thus, as 
the amount of whey added to the medium is increased, the $\mathrm{pH}$ elevates.

The effect among the foods occurred because ammonia is the result of the fermentation process of protein; hence why trypticase showed the highest amount of ammonia. Trypticase is a protein source of easy degradation. Inversely, carboxymethyl cellulose and starch are sources of carbohydrates. The lowest value was obtained by carboxymethyl cellulose for ammonia production with an average of $7.64 \mathrm{mg} / \mathrm{dL}$. It possibly occurred because the added whey already has a greater amount of ammonia due to its fermentation.

Monensin reduced ammonia production only when trypticase was used with substrate (Table 5), but did not reduce it in treatments containing starch and fiber, corroborating Russell and Strobel (1989), who claim that the ionophores have better results in diets containing a high degradable protein/fermentable carbohydrate ratio. The large amount of ammonia produced when the substrate was trypticase was due to the high degradability of its protein, which is consistent with the results found by Oliveira et al. (2004). This reduction in ammonia production was due to inhibition of microbial populations with high capacity of deamination of amino acids (Chen and Russell, 1989). Flythe (2009) observed that plants with high monensin contents inhibit bacteria that produce ammonia. This may be because ionophores are membranesoluble molecules that shuttle ions down the transmembrane concentration gradients (Flythe, 2009). The dissipation of these gradients causes the loss of the ionmotive forces that drive membrane transport proteins, power motility and maintain cell turgor (Flythe, 2009).

The effect $(\mathrm{P}<0.05)$ among the different foods occurred because ammonia is the result of the fermentation process of protein (Table 6), which presented the highest mean values when incubated with trypticase and had no statistical difference when incubated with starch or fiber.

The effect $(\mathrm{P}<0.05)$ of fermented whey on ammonia production at 24 hours was observed differently among the different incubated foods. When trypticase was used as substrate, it presented a quadratic behavior with or without monensin, indicating that the addition of larger quantities of fermented whey in the medium may provide toxic levels of lactic acid and propionic acid, inhibiting the growth of these microorganisms.

When starch was used as substrate, it increased linearly as the levels of fermented whey were added. This is related to the increase in the concentration of ruminal microorganisms in the medium, in which addition of whey containing organic acids causes an increase in fermentation of proteolytic microorganisms, and consequently greater ammonia production.

For the substrate fiber, a linear effect was observed when monensin was not present, which is reported in the preceding paragraph, by the increase in the amount of organic acids with the addition of whey. On the other hand, when there was monensin in the medium, it had a quadratic behavior, probably because monensin inhibited microbial populations with high capacity of deamination of amino acids (Chen and Russell, 1989).

The increase observed as fermented whey was added was precisely due to the microorganisms contained therein (Table 6).

Monensin inhibited microbial growth (Table 7), as it was also reported for ammonia, in which monensin inhibits the growth of microbial populations, especially grampositive bacteria (Martinele et al., 2008).

For the different foods, a higher microbial growth was observed in the medium in which the substrate was the starch. This increased microbial growth in part of amylolytic bacteria is because they have a faster fermentation than the cellulolytic and proteolytic bacteria.

The positive effect $(\mathrm{P}<0.05)$ found with the addition of whey on microbial protein concentration is probably because the organic acids contained in the whey stimulated microbial growth and whey constituents possibly served as a nutrient source for the microorganisms, as noted at 0 hour, when the same effect occurred. Brown et al. (2006), in the studies reviewed, verified that amylolytic bacteria became more numerous as more dietary concentrate was fed and lactate-utilizing bacteria increased more dramatically when the diet contained more than approximately $60 \%$ concentrate. Thus, whey probably enhanced lactateutilizing bacteria because it contained lactate.

The combination of whey fermented by bacteria Enterococcus faecium and Veilonella parvula and the antibiotic monensin had variable results with respect to the parameters evaluated. Therefore, no benefit was found for the use of these two substances combined.

There was an effect of whey fermented by bacteria Enterococcus faecium and Veilonella parvula on the proteolytic microorganisms, fibrouscarbohydrate fermenters and non-fibrous carbohydrate fermenters. However, the proteolytic bacteria were the most affected by fermented whey. This demonstrates that bacteria that ferment amino acids are sensitive to propionic and lactic acids contained in fermented whey.

The use of whey fermented by Enterococcus faecium and Veilonella parvula improves microbial protein synthesis by ruminal bacteria in media containing different energy 
sources (protein, fibrous carbohydrates and non-fibrous carbohydrates).

\section{Conclusions}

The use of whey fermented by bacteria Enterococcus faecium and Veilonella parvula improves microbial protein synthesis by ruminal bacteria in media containing different energy sources (protein, fibrous carbohydrates and nonfibrous carbohydrates).

The combination of whey fermented by bacteria Enterococcus faecium and Veilonella parvula and the antibiotic monensin has variable results in terms of microbial growth.

\section{References}

Bradford, M. M. 1976. A rapid and sensitive method for the quantitation of microgram quantities of protein utilizing the principle of proteindye binding. Analytical Biochemistry 72:248-254.

Brown, M. S.; Ponce, C. H. and Pulikanti, R. 2006. Adaptation of beef cattle to high-concentrate diets: Performance and ruminal metabolism. Journal of Animal Science 84:25-33.

Castillo, C.; Benedito, J. L.; Méndez, J.; Pereira, V.; López-Alonso, M.; Miranda, M. and Hernández, J. 2004. Organic acids as a substitute for monensin in diets for beef cattle. Animal Feed Science and Technology 115:101-116.

Chaney, A. L. and Marbach, E. P. 1962. Modified reagents for determination of urea and ammonia. Clinical Chemistry 8:130-132.

Chen, G. and Russell, J. B. 1989. More monensin-sensitive, ammoniaproducing bacteria from the rumen. Applied and Environmental Microbiology 55:1052-1057.

Flythe, M. D. 2009. The antimicrobial effects of hops (Humulus lupulus L.) on ruminal hyper ammonia-producing bacteria. Applied Microbiology 48:712-717.

Krehbiel, C. R.; Rust, S. R.; Zhang, G. and Gilliland, S. E. 2003. Bacterial direct-fed microabials in ruminant diets: performance response and mode of action. Journal of Dairy Science 81:E120-E132.

Lana, R. P.; Leopoldino, W. M.; Oliveira, J. S.; Veloso, R. G.; Nunes, P. M. M. and Queiroz, A. C. 2007. Parâmetros da degradação protéica ruminal de diferentes alimentos e rações estimados por técnica in vitro. Arquivo Brasileiro de Medicina Veterinária e Zootecnia 59:414-422.

Leopoldino, W. M.; Lana, R. P.; Borges, A. C.; Mantovani, H. C.; Teixeira, R. M. A.; Oliveira, J. S.; Jaremtchuk, A. R.; Eifert, E. C. and Martins, R. G. R. 2005. Efeito do $\mathrm{pH}$ in vitro sobre a resistência de bactérias do rúmen à perda de potássio intracelular e efeito do $\mathrm{pH}$ e de ionóforos sobre a produção de amônia e proteína microbiana. Arquivo Brasileiro de Medicina Veterinária e Zootecnia 57:777-783.

Martinele, I.; Eifert, E. C.; Lana, R. P.; Arcuri, P. B. and D‘Agosto, M. 2008. Efeito da monensina e do óleo de soja sobre os protozoários ciliados do rúmen e correlação dos protozoários com parâmetros da fermentação ruminal e digestivos. Revista Brasileira de Zootecnia $37: 1129-1136$.

Oliveira, J. S.; Lana, R. P.; Borges, A. C.; Queiroz, A. C. and Almeida, I. C. C. 2004. Efeito da monensina e extrato de própolis sobre a produção de amônia e degradabilidade in vitro da proteína bruta de diferentes fontes de nitrogênio. Revista Brasileira de Zootecnia 33:504-510

Oliveira, M. V. M.; Lana, R. P.; Jham, G. N.; Pereira, J. C.; Pérez, J. R. O. and Valadares Filho, S. C. 2005. Influência da monensina no consumo e na fermentação ruminal em bovinos recebendo dietas com teores baixo e alto de proteína. Revista Brasileira de Zootecnia 34:1763-1774.

Raeth-Knight, M. L.; Linn, J. G. and Jung, H. G. 2007. Effect of direct-fed microbials on performance, diet digestibility, and rumen characteristics of Hostein dairy cows. Journal of Dairy Science 90:1802-1809.

Ribeiro, M. D.; Pereira, J. C.; Queiroz, A. C.; Bettero, V. P.; Mantovani, H. C. and Silva, C. J. 2009. Influence of intraruminal infusion of propionic acid and forage to concentrate levels on intake, digestibility and rumen characteristics in young bulls. Revista Brasileira de Zootecnia 38:948-955.

Russell, J. M. 2002. Rumen microbiology and its role in ruminant nutrition. Ithaca, New York.

Russell, J. B. and Strobel, H. J. 2005. Microbial energetics. p.229-261. In: Quantitative aspects of ruminant digestion and metabolism. 2nd ed. Dijkstra, J.; Forbes, J. M. and France, J., eds. CABI, Wallingford.

Russell, J. B. and Strobel, H. J. 1989. Mini-review: the effect of ionophores on ruminal fermentation. Applied and Environmental Microbiology 55:1-6.

Weinberg, Z. G.; Muck, R. E. and Welmer, P. J. 2003. The survival of silage inoculant lactic acid bacteria in rumen fluid. Journal of Applied Microbiology 94:1066-1071. 